FACTA UNIVERSITATIS

Series: Economics and Organization Vol. 16, No 4, 2019, pp. 415 - 427

https://doi.org/10.22190/FUEO1904415V

Original Scientific Paper

\title{
THE RELATION BETWEEN MULTINATIONAL COMPANIES AND THE REPUBLIC OF SERBIA: INCOME TAXATION CONTEXT
}

\author{
UDC 336.226.14(497.11)
}

\section{Stefan Vržina, Nenad Janković}

University of Kragujevac, Faculty of Economics, the Republic of Serbia

\begin{abstract}
Host countries, especially developing countries, often grant tax incentives in order to attract foreign capital of multinational companies (MNCs), expecting positive effects of foreign direct investments on their economic development. Also, there is an opinion dominant in the literature that MNCs have enough power to achieve considerable tax incentives in negotiations with host country. Considering that one $M N C$ was granted considerable tax incentives from the Republic of Serbia (RS), the paper examines whether subsidiaries of MNCs have more favorable tax treatment of recorded income than domestic companies in the RS. Statistical analysis outcomes show that subsidiaries of MNCs do not have significantly lower income tax burden than domestic companies suggesting that tax incentives granted to MNCs from the RS are an exception rather than a rule. In addition, research showed that subsidiaries of MNCs primarily use tax incentives that are equally available to domestic companies, such as tax incentives for investment in fixed assets. Research results are robust to changes of income tax burden measures.
\end{abstract}

Key words: multinational companies, domestic companies, host countries, income tax, tax incentives, the Republic of Serbia

JEL Classification: F21, F23, H25, H26

\section{INTRODUCTION}

In order to attract foreign direct investments (FDIs), many countries offer substantial incentives. In particular, this relates to developing and less-developed countries. De Mello (1997) lists tax incentives (tax rebates and tax exemptions), financial incentives

Received June 11, 2019 / Revised September 24, 2019 / Accepted October 02, 2019

Corresponding author: Sefan Vržina

University of Kragujevac, Faculty of Economics, Liceja Kneževnine Srbije 3, 34000 Kragujevac, Serbia

E-mail: stefan.vrzina@kg.ac.rs 
(subsidized loans and grants) and non-financial incentives (infrastructure provision) as most important types of incentives.

Although prior research in developing and less-developed countries (Beyer, 2002; Cleeve, 2008; Klemm \& Van Parys, 2012) only partially finds positive impact of tax incentives on FDIs inflow, governments of these countries still offer important tax incentives to foreign investors. In this regard, Rajan (2004) points out at "fiscal war" between these countries in pursuit for FDIs.

Multinational companies (MNCs) providing important share of FDIs with their investments into developing countries rapidly grew in the last few decades (Buthe \& Milner, 2008). The relation between MNCs and host countries (countries that attract FDIs) may vary from negative and confrontational to positive and cooperative. Prior research (Sanyal \& Guvenli, 2000; Luo, 2001) finds that cooperative relation between MNC and host country is a significant determinant of MNC performance in host country.

Motivation for the research is found in special tax incentives granted to the largest subsidiary of MNCs in the Republic of Serbia (RS). It is worth noting that this subsidiary contributed a lot to recovery of Serbian automotive industry (Kocić et al., 2017). On the other hand, this subsidiary enjoys important tax incentives from the RS. In addition, prior research in this area is scarce since the aggregate data on tax incentives granted from the RS is not publicly available (Radenković, 2016, p. 74).

Research subject of this paper is the relation between MNCs and the RS with focus on income tax incentives granted by the RS. Income tax is chosen since foreign investors in Serbia value income tax incentives more than any other tax incentive (Domazet et al., 2018). Research objective is to examine whether MNCs are granted special income tax incentives by the RS, through comparison of income tax burden of subsidiaries of MNCs and domestic companies.

For the purposes of this paper, MNC is defined as a company incorporated in one country with subsidiaries in at least two foreign countries, while domestic company is defined as a company owned by individual residents of the RS. Income tax burden is measured by two effective income tax rates: Current and Cash effective income tax rates.

In line with defined research subject and objective, the following null and alternative research hypotheses are tested in the paper:

$H_{0}$ : $\quad$ MNC subsidiaries do not have lower effective income tax rates than domestic companies in the $R S$.

$H_{1}$ : MNC subsidiaries have lower effective income tax rates than domestic companies in the $R S$.

Research contributes to the existing, primarily foreign, research on the relation between MNCs and host countries. To authors' knowledge, this is the first research of this type in the RS. Research results can be of interest for owners and management of MNCs when deciding on investment in the RS, as well as for fiscal policymakers when assessing the fairness of income tax system of the RS.

Besides introduction and conclusion, the paper consists of three sections. The first section gives an overview on sources of power of MNCs that provide them a more powerful position compared to host countries. In the second section, the power of MNCs in the RS is analyzed, while research methodology and results are given in the third section. 


\section{SOURCES OF POWER OF MULTINATIONAL COMPANIES}

MNCs have one of the key roles in shaping modern economics. They influence the international trade and government policies worldwide, thus influencing economic development of countries (Macleod \& Lewis, 2004). Rondinelli (2002) argues that directors and associations of MNCs have a substantial influence on social, economic and environmental policy of many countries.

Due to their size (as measured by total assets or revenue), MNCs are often more powerful than host countries, in particular small and less-developed countries. MNCs such as ExxonMobil, General Electric, General Motors, Ford, Toyota and Walmart record annual revenue higher than gross national product (Rondinelli, 2002) or public revenue (Global Justice Now, 2016) of most countries. ${ }^{1}$

Position of MNCs is often determined by relative power of MNC and host country. Tarzi (1991) lists three basic sources of power of MNCs:

- a large share of total stock of investment, production and sales in the host country;

- domination in key industries of the host country and

- monopoly or oligopoly power in highly concentrated industries (e.g. petroleum or chemicals) of the host country.

Position of MNCs is also influenced by relative bargaining power of MNC and host country. Ramamurti (2001) argues that both MNCs and host countries have many sources of bargaining power since they have many benefits to offer each other. Due to advanced technology, product differentiation and large capital, MNCs may foster competition and export of the host country. On the other hand, the power of host countries is based on granting access to home market, national resources, local labor and a variety of incentives.

Important source of MNCs power comes from support of the parent country. Boddewyn (2016) stresses that many MNCs headquartered in emerging countries are state-owned or subsidized. In addition, Alden \& Davies (2006) argue that MNCs headquartered in China have a large parent country support (including tax incentives) in order to become key global market players.

The power of MNCs is larger as they contribute more to the economic development of host country. MNCs may be important source of export and export competitiveness of host country, particularly if they are engaged in production (rather than trade or financial) sector of economy (Estrin \& Uvalić, 2016).

Since MNCs may strengthen macroeconomics of the (primarily developing and lessdeveloped) host country, they can negotiate many benefits with the local government. Blomstrom et al. (2003) argue that many countries lowered barriers for FDIs inflow, expecting higher employment, export and technological development as a result. On the other hand, Jensen (2003) concludes that host country citizens often bear substantial costs of incentives granted to MNCs.

Bitzenis et al. (2009) treat taxes as important barrier for investment of MNCs into transition economies. In this regard, Vogiatzoglou (2018) finds that many Eastern European countries have lowered the tax rates to attract foreign investors. Due to their

\footnotetext{
${ }^{1}$ It is also possible to find opposite opinion. De Grauwe \& Camerman (2003) use value added instead of total assets or revenue to measure MNCs size and compare it to the GDP (a macroeconomic value added measure). Measuring the value added as a sum of pre-tax income, labor and depreciation costs, they conclude that MNCs are indeed much smaller (i.e. less powerful) than previously argued.
} 
power, MNCs can negotiate additional tax incentives, thus having a lower tax burden than other companies.

Countries with preferential tax system (tax havens) increase the power of MNCs (Ruggie, 2018). MNCs often invest in host countries through countries with preferential tax system in order to shift income recorded in host country to other countries (parent country or tax haven) with minimal tax paid.

On the other hand, MNCs may abuse dominant position in host country. MNCs often arrange aggressive transfer pricing system (related-party transactions valuation system) to minimize income tax expense. Most of the countries are not powerful enough to sanction such MNCs behavior - some of the rare examples are penalties paid by GlaxoSmithKline (Gujarathi, 2007) and Apple (Barrera \& Bustamante, 2018) following the decisions of United States tax authorities and European Commission, respectively.

Siegfried (1972) developed a theory (known as political power hypothesis) of negative relation between company size and effective tax burden. The theory suggests that larger and more powerful companies are able to lobby national tax authorities to reduce tax expense. Larger companies also have more resources to invest in tax advising to avoid taxes. Abundant empirical research (Guha, 2007; Richardson \& Lanis, 2007; Hsieh, 2012) confirmed political power hypothesis, at least partially.

\section{POWER OF MULTINATIONAL COMPANIES IN THE REPUBliC OF SERBIA}

As a leading FDI provider, MNCs considerably influence economy of the RS. Kastratović (2016) argues that FDIs may positively influence economic growth and development of the RS, while Popov (2010) points out at necessity of FDIs to achieve economic stability of the RS.

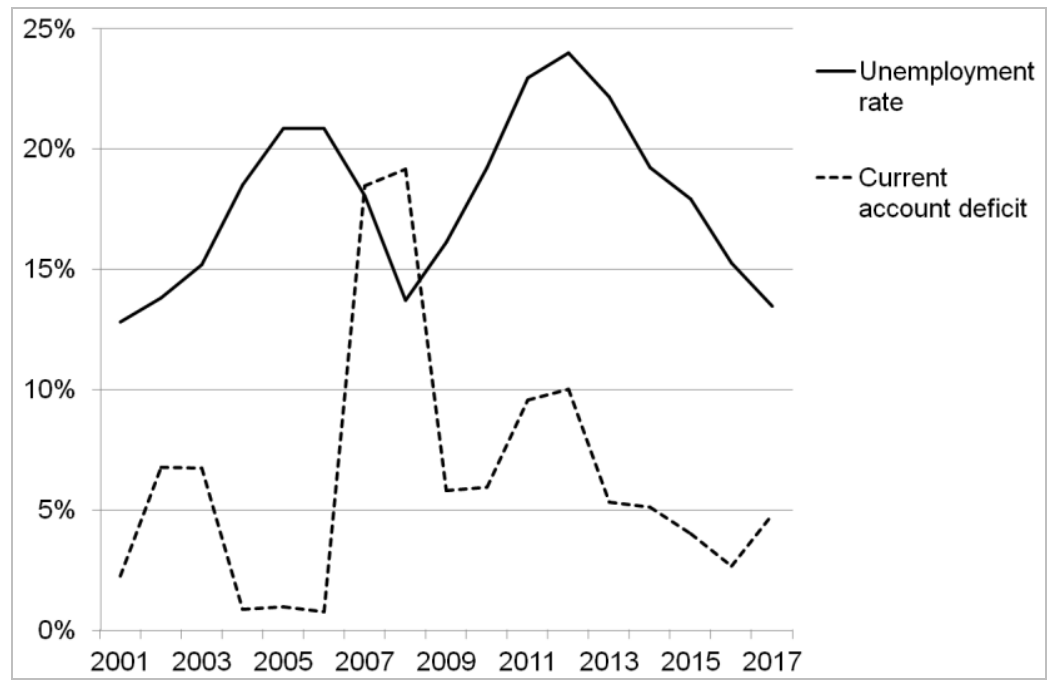

Fig. 1 Unemployment rate and current account deficit as a percent of GDP in the RS between 2001 and 2017

Source: Authors; based on World Bank (data.worldbank.org/country/serbia) and UNCTAD (unctadstat.unctad.org) data. 
MNCs also have an important share in employment of the RS since significant portion of labor is employed in Serbian subsidiaries of MNCs. Boljanović \& Hadžić (2017) emphasize the importance of FDIs for export, export competitiveness and productivity of the RS, while Đorđević (2015) argues that MNCs may be a solution for unemployment and balance-of-payments deficit problems.

However, the impact of FDIs on key macroeconomic indicators of the RS is still unclear, partially due to the global economic crisis. Figure 1 presents unemployment and current account deficit of the RS between 2001 and 2017, showing that these indicators have not changed considerably.

Year 2001 is chosen as a starting year since the foreign capital inflows in the RS intensified after 2000 when Serbia opened the economy to the world. Unemployment rate has been reduced in 2007 and 2008, partially as a result of high FDI inflows in 2006. In addition, unemployment rate continuously declines since 2012. Đorđević (2015) argues that FDIs did not significantly impact unemployment since they are dominantly realized as privatizations, not greenfield investments. On the other hand, current account deficit in balance-of-payments has been considerably increased in 2007 and 2008, primarily as a result of global economic crisis. It is also worth noting that the RS has surplus in services trade and high deficit in merchandise trade.

Observing period between 2008 and 2017, Business Info Group (2018) finds 13 subsidiaries of MNCs among the 15 largest exporters in the RS. Jeremić et al. (2015) find high concentration of Serbian export, dominated by a small number of foreign companies. On the other hand, among the 12 largest net exporters in the RS there are only seven MNC subsidiaries, indicating significant import activities of subsidiaries of MNCs in the RS. Therefore, it is necessary to be careful when assessing impact of MNCs on reduction of balance-of-payments deficit.

Ilić et al. (2018) find that MNCs have privatized many Serbian companies and increased their competitiveness, efficiency and profitability. MNCs had important role in privatization of both real and financial sector companies (Kekić, 2005) and also had important share in greenfield investments (Domanović \& Stojadinović Jovanović, 2017).

Global Justice Now (2016) analyzed revenues of MNCs and countries and listed 199 companies with annual revenue higher than public revenue of the RS. In this regard, these companies might be considered as more powerful than the RS. However, it should be noted that many of these companies do not have a subsidiary in the RS.

In general, MNCs income in the RS has the same tax treatment as income of other companies. Statutory income tax rate in the RS is $15 \%$ and it can be considered as relatively low. Gravelle (2009) argues that MNCs management often treats countries with statutory income tax rate lower than $20 \%$ as countries with preferential tax system (though assessment of income tax burden should not include only statutory income tax rate, but also the rules for taxable income calculation, tax exemptions, incentives and credits). MNCs can also benefit from the investment in the RS through many double tax treaties that the RS signed with other countries.

An impact of MNCs on the RS can be perceived through example of the largest MNC subsidiary in the RS, operating in automotive industry. Two thirds of the subsidiary's capital is owned by MNC, while one third belongs to the RS. According to the Business Info Group (2018), it is the largest exporter and net exporter in the RS, thus considerably shaping the RS economy. Founded in 2008, the subsidiary negotiated important tax incentives from the RS, disclosed in their annual financial reports: 
A company has a right on different incentives and tax exemptions. Some of them include: refund of social contributions paid for each employee, ten-year income tax exemption starting from the first year in which taxable income is recorded, exemption of local taxes (property tax, urban plan implementation tax, trademark presentation tax etc.)

Regarding income tax, this subsidiary makes significant tax savings. Table 1 presents income statement part related to income tax of this subsidiary, based on the Business Registers Agency of the RS (www.apr.gov.rs) data.

Table 1 Income statement part related to income tax of the studied subsidiary between 2010 and 2017

\begin{tabular}{|c|c|c|c|c|}
\hline \multirow{2}{*}{ Position } & \multicolumn{4}{|c|}{ Amount (in 000 Serbian dinars) } \\
\hline & 2010 & 2011 & 2012 & 2013 \\
\hline Pre-tax income & 548,137 & $-5,698,875$ & $-1,863,164$ & $1,166,176$ \\
\hline Current income tax expense & 0 & 0 & 0 & 0 \\
\hline Deferred income tax expense (revenue) & $(7,428)$ & $(14,451)$ & $(1,640,802)$ & 34,875 \\
\hline Net income & 555,565 & $-5,684,424$ & $-222,362$ & $1,131,301$ \\
\hline \multirow{2}{*}{ Position } & \multicolumn{4}{|c|}{ Amount (in 000 Serbian dinars) } \\
\hline & 2014 & 2015 & 2016 & 2017 \\
\hline Pre-tax income & $2,346,403$ & $2,352,261$ & $2,105,405$ & $2,295,657$ \\
\hline Current income tax expense & 0 & 0 & 0 & 0 \\
\hline Deferred income tax expense (revenue) & $(118,955)$ & $(31,379)$ & $(17,297)$ & 164,379 \\
\hline Net income & $2,465,358$ & $2,383,640$ & $2,122,702$ & $2,131,278$ \\
\hline
\end{tabular}

Source: Authors; based on the Business Registers Agency of the RS (www.apr.gov.rs) data.

Despite substantial tax incentives granted to studied subsidiary, it should be noted that the RS was not the only Balkan investment option for this MNC (Trifunović et al., 2009). As a result, Estrin \& Uvalić (2016) argue that such incentives were necessary to motivate this investor to invest in the RS, indicating that the investment without incentives was not the most profitable option for foreign investor.

\section{EMPIRICAL RESEARCH}

\subsection{Research methodology and sample development}

Empirical research is conducted on the basis of financial data of 100 companies: 50 subsidiaries of MNCs and 50 domestic companies. Research captured the period between 2014 and 2017. In order to test sensitivity of the research results, two income tax burden measures are used - Current effective income tax rate (ETR1) and Cash effective income tax rate (ETR2).

According to Global Justice Now (2016) data, there are 20 sampled subsidiaries of MNCs whose annual revenue is higher than public revenue of the RS. Additional 11 subsidiaries are sampled from the Business Info Group (2018) lists: a hundred companies with the highest operating revenue and a hundred companies with the highest net income in the RS between 2008 and 2017. The remaining 19 companies are randomly selected. On the other hand, a sample comprises 31 domestic companies appearing in two mentioned Business Info Group (2018) lists. The remaining 19 companies are randomly selected. In 
order to ensure reliability of the data, only companies with audited statutory financial reports for 2017 are sampled.

As of $1^{\text {st }}$ January 2019, 14 sampled subsidiaries are directly owned by Dutch entities of MNCs. Since the Netherlands are considered as the largest conduit country in profit shifting to tax havens (Weyzig, 2013), the research supports Ruggie (2018) arguing that MNCs tend to organize their foreign investments through entities in such countries.

Sampling 100 companies across four-year period, an initial sample comprises 400 observations. However, there are 34 observations withdrawn due to pre-tax loss in order to avoid negative effective income tax rates. Therefore, final sample comprises 366 observations.

Financial data used in the research have been retrieved from statutory financial reports published on the website of the Business Registers Agency of the RS (www.apr.gov.rs). Statistical data processing has been conducted in SPSS (Statistical Package for Social Sciences) and EViews.

Regarding statistical methods, tests of equality of independent groups are conducted in the paper. In order to control the impact of other company-specific variables, multiple regression analysis is also conducted. Through regression analysis, the impact of ownership type (MNC ownership or domestic ownership, OWN) on effective income tax rates (ETR1 and ETR2) is examined. In line with prior research (Guha, 2007; Richardson \& Lanis, 2007; Hsieh, 2012), the following control variables are used in the paper: size (SIZE), leverage (LEV), profitability (PROF) and capital intensity (CAPIT) of companies. Definitions of employed variables are given in Table 2.

Table 2 Variables definition

\begin{tabular}{ll}
\hline Variable label & Formula \\
\hline ETR1 & (Current income tax expense / Pre-tax income) x 100 \\
ETR2 & (Income tax paid / Pre-tax income) x 100 \\
OWN & 0 if MNC ownership; 1 if domestic ownership \\
SIZE & Natural logarithm of total assets (in 000 Serbian dinars) \\
LEV & Total liabilities / Total assets \\
PROF & (Pre-tax income / Total assets) x 100 \\
CAPIT & Fixed assets / Total assets \\
\hline
\end{tabular}

In line with defined variables, it is possible to formulate the following regression model:

$$
E T R_{i, t}=\alpha+\beta_{1} O W N_{i, t}+\beta_{2} S I Z E_{i, t}+\beta_{3} L E V_{i, t}+\beta_{4} P R O F_{i, t}+\beta_{5} C A P I T_{i, t}+\varepsilon_{i, t}
$$

where ETR refers to ETR1 and ETR2.

\subsection{Research results}

\subsubsection{Descriptive statistics}

Table 3 shows descriptive statistics. On the average, effective income tax rates are lower than statutory income tax rate of $15 \%$, though with some three-digit extreme values. LEV is in eight observations (each refers to subsidiaries of MNCs) higher than one, indicating losses above owners' capital. It is interesting to note that two observations with highest PROF regard the same company engaged in betting industry. 
Table 3 Descriptive statistics

\begin{tabular}{|c|c|c|c|c|c|}
\hline Variable & Mean & Minimum & Median & Maximum & $\begin{array}{l}\text { Standard } \\
\text { deviation }\end{array}$ \\
\hline \multicolumn{6}{|c|}{ Panel A. Descriptive statistics at the whole sample level } \\
\hline ETR1 & $12.183 \%$ & $0.000 \%$ & $11.786 \%$ & $113.076 \%$ & $12.278 \%$ \\
\hline ETR2 & $14.874 \%$ & $0.000 \%$ & $9.628 \%$ & $405.458 \%$ & $29.623 \%$ \\
\hline OWN & \multicolumn{5}{|c|}{ Value $0-171$ observations; Value $1-195$ observations } \\
\hline SIZE & 15.152 & 12.022 & 15.094 & 19.807 & 1.245 \\
\hline LEV & 0.521 & 0.053 & 0.526 & 4.353 & 0.338 \\
\hline PROF & $10.254 \%$ & $0.024 \%$ & $8.080 \%$ & $83.330 \%$ & $10.185 \%$ \\
\hline CAPIT & 0.394 & 0.004 & 0.399 & 0.823 & 0.227 \\
\hline \multicolumn{6}{|c|}{ Panel B. ETR 1 by the ownership type } \\
\hline MNC subsic & $12.970 \%$ & 0.000 & 11.62 & $113.076 \%$ & $15.656 \%$ \\
\hline Domestic companies & $11.493 \%$ & $0.000 \%$ & $11.839 \%$ & $68.426 \%$ & $8.235 \%$ \\
\hline \multicolumn{6}{|c|}{ Panel C. ETR2 by the ownership type } \\
\hline MNC subsidiaries & $16.677 \%$ & $0.000 \%$ & $4.694 \%$ & $405.458 \%$ & $40.488 \%$ \\
\hline Domestic companies & $13.292 \%$ & $0.000 \%$ & $11.567 \%$ & $103.647 \%$ & $14.462 \%$ \\
\hline
\end{tabular}

Regarding ETR1 and ETR2, mean and median offer different conclusions. Mean results indicate that subsidiaries of MNCs have higher income tax burden, supporting the null hypothesis. However, median results indicate opposite results, supporting the alternative hypothesis.

It is interesting to note that there are three subsidiaries of MNCs and two domestic companies having a null current income tax expense despite recorded pre-tax income in each observed year. One of the subsidiaries, already mentioned in the second section of the paper, has special tax exemptions though it has a right to use investment tax incentive. Other two subsidiaries use foreign dividend tax credit and investment tax incentive. Two domestic companies also use investment tax incentive to lower their ETR1 to 0\%.

\subsubsection{Statistical tests}

Table 4 shows the results of independent samples t-tests examining significance of difference between subsidiaries of MNCs and domestic companies in ETR1 and ETR2.

Table 4 Results of independent samples t-tests

\begin{tabular}{llccccc}
\hline & & \multicolumn{2}{c}{$\begin{array}{c}\text { Levene's Test for } \\
\text { Equality of Variances }\end{array}$} & \multicolumn{2}{c}{ t-test for Equality of Means } \\
\cline { 3 - 7 } & & $\mathrm{F}$ & $\mathrm{Sig}$. & $\mathrm{t}$ & $\mathrm{df}$ & $\begin{array}{c}\text { Sig. } \\
\text { (2-tailed) }\end{array}$ \\
\hline \multirow{2}{*}{ ETR1 } & & & & & & \\
& & & & & &
\end{tabular}

Although subsidiaries of MNCs have higher mean ETR1 and ETR2, and lower median ETR1 and ETR2, independent samples t-tests suggest that these differences are not statistically significant. Since Levene's test p-value is 0.000 , it is more appropriate to rely on "Equal variances not assumed" results. 
It should be noted that independent samples t-tests examine only the impact of ownership type on effective income tax rates without accounting for potential impact of other variables that influence effective income tax rates. Therefore, multiple regression analysis is employed in order to control the impact of ownership type on effective income tax rates for variability in company size, leverage, profitability and capital intensity.

\subsubsection{Correlation analysis}

Table 5 shows correlation matrix with Pearson's coefficients reported. Results show that effective income tax rates are strongly positively correlated, while ownership type does not exhibit significant correlation with either ETR1 or ETR2.

Table 5 Pearson's correlation matrix

\begin{tabular}{|c|c|c|c|c|c|c|c|}
\hline & ETR1 & ETR2 & OWN & SIZE & LEV & PROF & CAPIT \\
\hline ETR1 & 1.000 & & & & & & \\
\hline ETR2 & ${ }^{* * *} 0.733$ & 1.000 & & & & & \\
\hline OWN & -0.060 & -0.057 & 1.000 & & & & \\
\hline SIZE & ${ }^{* * *}-0.331$ & ${ }^{* * * *}-0.176$ & 0.054 & 1.000 & & & \\
\hline LEV & 0.010 & -0.041 & ${ }^{* *}-0.126$ & ** -0.107 & 1.000 & & \\
\hline PROF & ${ }^{*}-0.095$ & ${ }^{* * * *}-0.141$ & -0.036 & ${ }^{*}-0.101$ & ${ }^{* * * *}-0.147$ & 1.000 & \\
\hline CAPIT & **** -0.397 & ${ }^{* * * *}-0.208$ & ${ }^{* * *} 0.210$ & ${ }^{* * *}-0.382$ & ${ }^{* * *}-0.143$ & -0.066 & 1.000 \\
\hline
\end{tabular}

Capital intensity is a variable that has the strongest correlation with both ETR1 and ETR2, though this correlation is only of medium magnitude. On the other hand, there is no strong correlation among independent variables, so multicollinearity problems are not expected.

\subsubsection{Regression analysis}

Table 6 shows multiple regression estimates. Since two effective income tax rate measures are used, there are two regression models to be reported. Table reports Ordinary

Table 6 Regression analysis estimates

\begin{tabular}{|c|c|c|c|c|}
\hline & \multicolumn{2}{|c|}{ Dependent: ETR1 } & \multicolumn{2}{|c|}{ Dependent: ETR2 } \\
\hline & $\mathrm{OLS}$ & Random-effects & OLS & Random-effects \\
\hline \multirow{2}{*}{ Intercept } & 56.743 & 58.245 & 85.181 & 86.250 \\
\hline & $(7.527)$ & $(5.556)$ & $(4.342)$ & $(4.086)$ \\
\hline \multirow{2}{*}{ OWN } & 0.155 & 0.530 & -1.977 & -1.828 \\
\hline & $(0.132)$ & $(0.315)$ & $(-0.646)$ & $(-0.553)$ \\
\hline \multirow{2}{*}{ SIZE } & ${ }^{* * * *}-2.249$ & ${ }^{* * * *}-2.241$ & $* * 3.265$ & ** -3.280 \\
\hline & $(-4.502)$ & $(-3.229)$ & $(-2.511)$ & $(-2.344)$ \\
\hline \multirow{2}{*}{ LEV } & $* 3.031$ & *** -4.084 & ***-9.901 & ***-9.992 \\
\hline & $(-1.737)$ & $(-2.016)$ & $(-2.180)$ & $(-2.146)$ \\
\hline \multirow{2}{*}{ PROF } & **** -0.183 & **** -0.297 & **** -0.538 & **** -0.614 \\
\hline & $(-3.195)$ & $(-4.564)$ & $(-3.611)$ & $(-3.973)$ \\
\hline \multirow{2}{*}{ CAPIT } & **** -18.023 & -18.721 & **** -23.104 & -23.529 \\
\hline & $(-6.449)$ & $(-4.893)$ & $(-3.177)$ & $(-3.014)$ \\
\hline Adjusted $\mathrm{R}^{2}$ & 0.210 & 0.140 & 0.081 & 0.075 \\
\hline F-value & *****20.431 & 12.849 & **** 7.450 & 6.930 \\
\hline
\end{tabular}

Note: Beta coefficients in front of the parentheses, t-statistics in the parentheses statistically significant at $10 \%\left(^{*}\right), 5 \%\left({ }^{* *}\right)$ and $1 \%\left(\left(^{* * *}\right)\right.$ level. 
Least Squares (OLS) and random-effects panel regression estimates. Breusch-Pagan Lagrange multiplier tests suggest that random-effects (OLS) analysis is more appropriate in first (second) reported model. Results of these tests are reported in Table 7.

It should also be noted that fixed-effects regression method cannot be employed in this research due to the near singular matrix problem since each company has the same OWN value ( 0 or 1$)$ in each observed year. Therefore, Hausman test is not conducted.

Table 7 Breusch-Pagan Lagrange Multiplier tests

\begin{tabular}{lccc}
\hline $\begin{array}{l}\text { Dependent } \\
\text { variable }\end{array}$ & Cross-section & Test Hypothesis Time & Both \\
\hline ETR1 & 65.583 & 1.431 & 67.014 \\
& $(0.000)$ & $(0.232)$ & $(0.000)$ \\
ETR2 & 2.137 & 0.966 & 3.104 \\
& $(0.144)$ & $(0.326)$ & $(0.078)$ \\
\hline \multicolumn{4}{c}{ Note: p-values in parentheses. }
\end{tabular}

According to the adjusted $\mathrm{R}^{2}$ values, presented models poorly explain variations of ETR1 and ETR2. OLS and random-effects regression estimates are highly consistent. They support the independent samples t-tests findings indicating that there is no significant difference between subsidiaries of MNCs and domestic companies in either ETR1 or ETR2. OWN is the only variable insignificant in any regression model. Regression results are robust to change of effective income tax rate measure.

It is necessary to point out that effective income tax rates of MNC subsidiaries may be lowered due to different tax incentives, not only the special tax incentives granted to them. For example, income tax burden can be considerably reduced using tax losses carryforward as tax losses can be carried forward in five-year period. In addition, the RS offers tax incentive for investment in fixed assets in ten-year period. Transfer pricing and tax consolidation rules enable further reduction of effective income tax rates.

Among other independent variables, larger companies have both ETR1 and ETR2 lower, supporting political power hypothesis. More leveraged companies also have lower effective income tax rates. In addition, more profitable companies have lower income tax burden as they have more resources to invest in tax avoidance activities. Companies with higher share of fixed assets in total assets have lower income tax burden that can be partially explained with investment tax incentives.

On the one hand, it is known that one MNC was granted important tax incentives from the RS but, on the other hand, there is no significant difference in either ETR1 or ETR2 between subsidiaries of MNCs and domestic companies. Therefore, the research suggests that special income tax incentives granted to MNCs from the Serbian government are rarity, rather than a rule. It is indicative that such incentives are given only to foreign investors of strategic importance for economic development of the RS.

Developing countries often treat automotive industry as a key factor of economic and technological development (Jan \& Hsiao, 2004). In addition, automotive industry significantly contributes to the gross domestic product and employment, particularly in industrial countries (Irandoust, 1999). Therefore, it is not surprising that an automotive industry MNC has been given special tax incentives in the RS.

Absence of special tax incentives does not mean that MNCs do not enjoy other types of incentives in the RS. For example, the RS made considerable financial incentives (i.e. 
grants) available to attract foreign capital. These financial incentives are regulated by special legal act - Regulation on Determining the Criteria for Granting the Incentives with a View to Attract Foreign Direct Investment (The Official Gazette of the RS, no. 1/2019).

\section{CONCLUSION}

Research in this paper captured 50 subsidiaries of MNCs and 50 domestic companies to examine whether MNCs enjoy special tax incentives granted from the RS, i.e. whether MNCs have more favorable income tax treatment than other companies in the RS. In this regard, two effective income tax rate measures are used: ETR1 (Current effective income tax rate) and ETR2 (Cash effective income tax rate).

In general, research results indicate that subsidiaries of MNCs do not have preferential income tax treatment. Results are robust to change in effective income tax rate measure. ETR1 and ETR2 mean results indicate that subsidiaries have higher income tax burden, while ETR1 and ETR2 median results suggest the opposite. However, these differences are not statistically significant.

It can be concluded that special tax incentives given to MNCs are rarity, rather than a rule. They are granted only to foreign investors of strategic importance for the RS economy, such as an automotive MNC analyzed in the second section of the paper. In addition, it is noticeable that subsidiaries of MNCs in the RS lower their income tax burden with mechanisms that are also available to domestic companies, such as investment tax incentive. Therefore, there is not enough evidence to reject null research hypothesis.

Research results have certain limitations. It is possible that results would be different if sample size or sampling period were changed. As there are important cross-country differences in tax systems and attitudes on FDIs importance, research results might be different in other countries. It is also necessary to point out that MNCs can avoid taxes through related-party transactions, not only through the host country support. Employed effective income tax rates do not capture effects of tax avoidance through such transactions.

Future research should include more companies and more host countries, primarily in South Eastern Europe, in order to compare results. Also, future research should tend to find additional determinants of effective income tax rates since employed independent variables poorly explain variations of effective income tax rates. Future research should also include other incentives granted to MNCs, not only income tax incentives.

Acknowledgement: This paper is part of the research project (number III 47005), financed by the Ministry of Education, Science and Technological Development of the Republic Serbia.

\section{REFERENCES}

Alden, C. \& Davies, M. (2006). A Profile of the Operations of Chinese Multinationals in Africa. South African Journal of International Affairs, 13 (1), 83-96, doi: 10.1080/10220460609556787

Barrera, R. \& Bustamante, J. (2018). The Rotten Apple: Tax Avoidance in Ireland. The International Trade Journal, 32 (1), 150-161, doi: 10.1080/08853908.2017.1356250

Beyer, J. (2002). 'Please Invest in Our Country' - How Successful were the Tax Incentives for Foreign Investment in Transition Countries? Communist and Post-Communist Studies, 35 (2), 191-211, doi: 10.1016/S0967-067X(02)00007-7 
Bitzenis, A., Tsitouras, A. \& Vlachos, V. (2009). Decisive FDI Obstacles as an Explanatory Reason for Limited FDI Inflows in an EMU Member State: The Case of Greece. The Journal of Socio-Economics, 38 (4), 691704, doi: 10.1016/j.socec.2009.03.001

Blomstrom, M., Kokko, A. \& Mucchielli, J. (2003). The Economics of Foreign Direct Investment Incentives. In: Hermann, H. \& Lipsey, R. (Eds.) Foreign Direct Investment in the Real and Financial Sector of Industrial Countries (pp. 37-60). Springer: Heildelberg, doi: 10.1007/978-3-540-24736-4_3

Boddewyn, J. (2016). International Business-Government Relations Research 1945-2015: Concepts, Typologies, Theories and Methodologies. Journal of World Business, 51 (1), 10-22, doi:10.1016/j.jwb. 2015.08.009

Boljanović, S. \& Hadžić, M. (2017). Impact of Foreign Direct Investments on Serbian Industry. Industrija, 45 (3), 39-64, doi: 10.5937/industrija45-13465

Business Info Group (2018). 100 najvećih, 100 najboljih 2008-2018 [100 Largest, 100 The Best 2008-2018], Retrieved from: www.big.co.rs/upload/Edition/Download/2018-10/Edicija100.pdf, Accessed on: 01 February 2019.

Buthe, T. \& Milner, H. (2008). The Politics of Foreign Direct Investment into Developing Countries: Increasing FDI through International Trade Agreements?. American Journal of Political Science, 52 (4), 741-762, doi: 10.1111/j.1540-5907.2008.00340.x

Cleeve, E. (2008). How Effective are Fiscal Incentives to Attract FDI to Sub-Saharan Africa?. Journal of Developing Areas, 42 (1), 135-153, doi: 10.2307/40376198

De Grauwe, P. \& Camerman, F. (2003). Are Multinationals Really Bigger than Nations?. World Economics, 4 (2), 23-37.

De Mello, L. (1997). Foreign Direct Investment in Developing Countries and Growth: A Selective Survey. The Journal of Development Studies, 34 (1), 1-34, doi: 10.1080/00220389708422501

Domanović, V. \& Stojadinović Jovanović, S. (2017). Effects of Foreign Direct Investments on Serbian Exporters' Profitability. Economic Themes, 55 (1), 1-23, doi: 10.1515/ethemes-2017-0001

Domazet, I., Marjanović, D. \& Stošić, I. (2018). Attractiveness of the Domicile Economy through Tax Incentives. Ekonomika preduzeća, 66 (7-8), 434-445, doi: 10.5937/EKOPRE1808434D

Đorđević, A. (2015). Transnational Corporations and the Effects of Their Operations on the Economy of Serbia. Bankarstvo, 44 (1), 48-77, doi:10.5937/bankarstvo1501048D

Estrin, S. \& Uvalić, M. (2016). Foreign Direct Investment in the Western Balkans: What Role Has it Played During Transition?. Comparative Economic Studies, 58 (3), 455-483, doi: 10.1057/ces.2016.10

Global Justice Now (2016). 10 Biggest Corporations Make More Money than Most Countries in the World Combined, Retrieved from: www.globaljustice.org.uk/news/2016/sep/12/10-biggest-corporations-makemore-money-most-countries-world-combined, Accessed on 01 February 2019.

Gravelle, J. (2009). Tax Havens: International Tax Avoidance and Evasion. National Tax Journal, 62 (4), $727-$ 753, doi: $10.17310 /$ ntj.2009.4.07

Gujarathi, M. (2007). GlaxoSmithKline Plc.: International Transfer Pricing and Taxation. Issues in Accounting Education, 22 (4), 749-759, doi: 10.2308/iace.2007.22.4.749

Guha, A. (2007). Company Size and Effective Corporate Tax Rate: Study on Indian Private Manufacturing Companies. Economic and Political Weekly, 42 (20), 1869-1874, doi: 10.2307/4419610

Hsieh, Y. (2012). New Evidence on Determinants of Corporate Effective Tax Rates. African Journal of Business Management, 6 (3), 1177-1180, doi: 10.5897/AJBM11.1522

Ilić, S., Bogojević, D. \& Branković, B. (2018). Role of Multinational Companies in the Process of Privatization of Companies in Serbia. EuroEconomica, 37 (1), $42-53$.

Irandoust, M. (1999). Market Structure and Market Shares in the Car Industry. Japan and the World Economy, 11 (4), 531-544, doi: 10.1016/S0922-1425(99)00013-4

Jan, T. \& Hsiao, C. (2004). A Four-Role Model of the Automotive Industry Development in Developing Countries: A Case in Taiwan. Journal of the Operational Research Society, 55 (11), 1145-1155, doi: $10.1057 /$ palgrave.jors. 2601776

Jensen, N. (2003). Democratic Governance and Multinational Corporations: Political Regimes and Inflows of Foreign Direct Investment. International Organization, 57 (3), 587-616, doi: 10.1017/S0020818303573040

Jeremić, Z., Milojević, M. \& Terzić, I. (2015). Business Performance of the Largest Exporters in Serbia during the Period 2008-2014. Ekonomika preduzeća, 63 (5-6), 293-305, doi: 10.5937/ekopre1506293J

Kastratović, R. (2016). The Influence of Foreign Direct Investments on Economic and Social Development of Serbia. Bankarstvo, 45 (4), 70-93, doi: 10.5937/bankarstvo1604070K

Kekić, L. (2005). Foreign Direct Investment in the Balkans: Recent Trends and Prospects. Southeast European and Black Sea Studies, 5 (2), 171-190, doi: 10.1080/14683850500122687

Klemm, A. \& Van Parys, S. (2012). Empirical Evidence on the Effects of Tax Incentives. International Tax and Public Finance, 19 (3), 393-423, doi: 10.1007/s10797-011-9194-8 
Kocić, M., Šapić, S. \& Golo, J. (2017). The Impact of Foreign Direct Investments on the Image of a City: The Example of Fiat Company and the City of Kragujevac. Teme, 41 (1), 119-137, doi: 10.22190/TEME1701119K

Luo, Y. (2001). Toward a Cooperative View of MNC-Host Government Relations: Building Blocks and Performance Implications. Journal of International Business Studies, 32 (3), 401-419, doi: 10.1057/palgrave. jibs. 8490974

Macleod, S. \& Lewis, D. (2004). Transnational Corporations: Power, Influence and Responsibility. Global Social Policy, 4 (1), 77-98, doi: 10.1177/1468018104040986

Popov, Đ. (2010). The Importance of Foreign Capital for the Economic Stability of Serbia. Transition Studies Review, 17 (4), 777-789, doi: 10.1007/s11300-010-0175-х

Radenković, I. (2004). Foreign Direct Investments in Serbia. Belgrade: Rosa Luxemburg Stiftung Southeast Europe.

Rajan, R. (2004). Measures to Attract FDI: Investment Promotion, Incentives and Policy Intervention. Economic and Political Weekly, 39 (1), 12-16, doi: 10.2307/4414454

Ramamurti, R. (2001). The Obsolescing 'Bargaining Model'? MNC-Host Developing Country Relations Revisited. Journal of International Business Studies, 32 (1), 23-39, doi: 10.1057/palgrave.jibs.8490936

Richardson, G. \& Lanis, R. (2007). Determinants of the Variability in Corporate Effective Tax Rates and Tax Reform: Evidence from Australia. Journal of Accounting and Public Policy, 26 (6), 689-704, doi: 10.1016/j.jaccpubpol.2007.10.003

Rondinelli, D. (2002). Transnational Corporations: International Citizens or New Sovereigns?. Business and Society Review, 107 (4), 391-413, doi: 10.1111/1467-8594.00143

Ruggie, J. (2018). Multinationals as Global Institution: Power, Authority and Relative Autonomy. Regulation \& Governance, 12 (3), 317-333, doi: 10.1111/rego.12154

Sanyal, R. \& Guvenli, T. (2000). Relations between Multinational Firms and Host Governments: The Experience of American-Owned Firms in China. International Business Review, 9 (1), 119-134, doi: 10.1016/S09695931(99)00032-3

Siegfried, J. (1972). The Relationship between Economic Structure and the Effect of Political Influence: Empirical Evidence from the Federal Corporation Income Tax Program. Ph.D. Thesis. University of Wisconsin.

Tarzi, S. (1991). Third World Governments and Multinational Corporations: Dynamics of Host's Bargaining Power. International Relations, 10 (3), 237-249, doi: 10.1177/004711789101000303

Trifunović, D., Ristić, B., Ivković, M., Tanasković, S., Italiano, L. \& Tattoni, S. (2009). FDI's Impact on Transitional Countries, Serbia as a Rational Choice: The Fiat-Zastava Case. Transition Studies Review, 16 (2), 269-286, doi: 10.1007/s11300-009-0064-3

Vogiatzoglou, K. (2018). Differences in Inward FDI Performance between the Southern Eurozone and Eastern EU Members: A Panel-Data Analysis Over 2004-2016. Economic Themes, 56 (4), 519-532.

Weyzig, F. (2013). Tax Treaty Shopping: Structural Determinants of Foreign Direct Investment Routed Through the Netherlands. International Tax and Public Finance, 20 (6), 910-937, doi: 10.1007/s10797$012-9250-\mathrm{z}$

\section{ODNOS MULTINACIONALNIH KOMPANIJA I REPUBLIKE SRBIJE: KONTEKST POREZA NA DOBITAK}

Zemlje domaćini, posebno zemlje u razvoju, neretko obezbeđuju poreske podsticaje kako bi privukle strani kapital multinacionalnih kompanija (MNK), očekujući pozitivne efekte stranih direktnih investicija na ekonomski razvoj zemlje. Takođe, u literaturi je dominirajuće mišljenje da MNK imaju dovoljno moći da, u pregovorima sa zemljom domaćinom, ostvare značajne poreske podsticaje. S obzirom na to da je jedna MNK dobila značajne poreske podsticaje od Republike Srbije (RS), u radu je ispitano da li filijale MNK imaju povoljniji poreski tretman dobitka u odnosu na domaće kompanije u RS. Rezultati statističke analize pokazuju da filijale MNK nemaju značajno niže opterećenje porezom na dobitak u odnosu na domaće kompanije, sugerišući da su poreski podsticaji koje dobijaju MNK od RS pre izuzetak, nego pravilo. Istraživanje je, takođe, pokazalo da filijale MNK primarno koriste poreske podsticaje koji su podjednako dostupni i domaćim kompanijama, kao što su poreski podsticaji po osnovu ulaganja u osnovna sredstva. Rezultati istraživanja su robusni na promene merila opterećenja porezom na dobitak.

Ključne reči: multinacionalne kompanije, domaće kompanije, zemlje domaćini, porez na dobitak, poreski podsticaji, Srbija. 